\title{
10. West Papuan journalists today An alternative human rights perspective from Indonesia
}

\begin{abstract}
This article examines the curiosity of journalists in West Papua about the notion of human rights. The selection of this theme as a focus of research can be seen as a concern for the role of journalists in the enforcement of human rights. The selection of West Papuan journalists for research departs from the position of journalists as perpetrators of journalism activities. The author has proposed four disciplines of writing news about human rights violations in West Papua: 1) the level of curiosity of the notion of human rights by West Papuan journalists, 2) the intellectual attitude of West Papuan journalists, 3) the terms of reference for practising journalism skills in writing news about human rights violations in West Papua, and 4) news about human rights violations in West Papua. To test the level of curiosity about human rights of West Papuan journalists, the author carried out indepth interviews with Benny Mawel (a journalist with tabloidjubi.com) and Arnold Belau (a journalist with suarapapua.com). The findings are discussed in terms of journalists as professionals. The author argues that that the focus on the notion of human rights in West Papua has begun to diminish.
\end{abstract}

Keywords: ethics, interviews, human rights journalism, human rights violations, Indonesia, journalism skills, West Papua, media ethics

\section{ANA NADHYA ABRAR \\ Universitas Gadjah Mada, Yogyakarta}

\section{Introduction}

$1 \mathrm{UCH}$ news has focused on human rights violations in West Papua in recent times. Regarding so much news as additional information about human rights violations in West Papua is certainly not wrong. However, the flood of information does not automatically turn into knowledge. In order to become knowledge, news, besides having to present information (the facts), also needs to present a reason (why).

Following this logic, the question arises whether the news of human rights violations in West Papua has become knowledge for an audience. It is not easy 
to answer this question without comprehensive research. What is clear is that news about human rights violations in West Papua is starting to show accountability to the conscience. As an example, consider the news item entitled 71 Years of Human Rights Day, A Blurred Portrait of Human Rights Violations in Papua (Ceposonline.com, 2019). It was stated that among other things the most violated are the right to life and the right to education. The news item added:

In addition, the matter of civil and political rights in 2019 also experienced gloom where there was mass violence that occurred throughout Papua and even West Papua. ${ }^{1}$ The situation of civil and political rights throughout 2019 illustrates the opaque situation because there was violence that occurred in a mass, massive and prolonged manner.

This quote shows that Ceposonline.com is free to report information in accordance with the facts in the field and its values. It was not worried about the attitude of the authorities after reading this news. It also does not care the audience would consider this news 'bad news'. The important thing is that it has conveyed information in accordance with its conscience.

In fact, newspapers in West Papua do not need to worry about government control. Since 23 September 1999, the Indonesian government no longer has the right to control the Indonesian press. This is confirmed by Law No. 40 about the press. Article 4 Paragraph 2 of the law states: 'The national press is not subject to censorship, banning or broadcasting prohibition'. Besides that, Article 3 Paragraph 1 of the Law states: 'The national press has a function as a medium of information, education, entertainment, and social control.' This confirms that newspapers in West Papua may exercise social control.

This fact can apparently be read as newspapers in West Papua can freely report news about human rights violations in West Papua. They can report the news of human rights violations in West Papua continuously in accordance with the existing reality. If this is the case, journalists in West Papua need to have great curiosity about the idea of human rights in West Papua. Without great curiosity, the practice of human rights journalism in West Papua cannot breathe. The problem that then arises is, do journalists in West Papua have great curiosity about the idea of human rights in West Papua?

This article seeks to answer that question based on interviews with journalists from tabloidjubi.com and suarapapua.com who are used to writing news about human rights violations in West Papua.

\section{Literature review}

Ashadi Siregar, a retired lecturer at Gadjah Mada University, Yogyakarta, writes: 
A journalist, in addition to mastering the standard technical skills in the field of journalism, must also know the position of the profession he runs in his audience. Then he also needs to have an awareness of the extent and scope of recipients of the information he conveys. This broad awareness of the target audience will make reporters maintain the nature of their information (1985, p. 7).

This quote shows that a journalist needs to know: 1) his position, 2) the position of the news audience, and 3) the nature of his information. Fulfillment of these three aspects would make the news he or she writes useful for the audience. These benefits should be seen from the side of audience, not from the side of journalists.

In other contexts, the fulfillment of the three aspects above makes journalists not lose their connection with their social environment. They become more responsible for their professional actions. They can also distinguish which news is important to write and which is not. This is why journalists must have a moral framework. This framework, according to Ana Nadhya Abrar, comprises 1) ethical values, 2) a code of ethics, 3) a media company code, and 4) a penal code (2015, p. 68)

However, every journalist's professional activity results from this process. One important element, argues Oscar Motuloh, is curiosity. He continues:

Because of journalist curiosity, journalism still breathes. It enters into every shutter and sense of journalism, from the mainstream to the current convergence, from the elegant to the coward, from the banal to the scandal, and from mysticism to politics. (2019, p. 228)

In line with this view, Elizabeth Winda, a Bisnis Indonesia journalist (2015), quotes Amanda Kusuma's opinion, in saying that high level of curiosity is the main basis of being a journalist. Therefore, without a greater curiosity reporters cannot do their jobs properly. This also applies to human rights journalists. This fact is implied through the meaning of human rights journalism as written by Ibrahim Seaga Shaw as follows:

Human rights journalism can be defined as a diagnostic style of reporting which offers a critical reflection of the experiences and needs of the victims and perpetrators of (physical, cultural and structural) human rights violations. (2011, p. 107)

This quote shows that human rights journalism strives to understand the reasons for these violations in order to prevent further violations and to solve current ones in ways that would not produce more violence. Because of this, a human rights journalist is an intellectual. He or she does not only react to human rights 
violations. They do not just fulfill the media rules without a serious reflection process.

According to Mohamad Sobary (1995), intellectuals are people's recognition of commitment, one's behavior in thinking. He continues:

They respond to the reality around them by processing thought and taste. They always ask, are anxious, and kept trying, without feeling satisfied, to get answers to all the metaphysical and socio-cultural puzzles around them. $(1995$, p. 190)

This quote shows that an intellectual person has dynamic anxiety and is driven by inquiry. He does that regularly to make changes. So human rights journalists are expected to have an intellectual attitude like this. The intellectual attitude of human rights journalists will be reflected again in the face of reality. In this context, Ashadi Siregar writes:

Reality basically comes from human life in the middle of nature. Not all reality can be faced directly by journalists. In practice he will use more human beings as a source of the reality he is processing. For that, he needs to have a critical attitude that never stops. $(1985$, p. 10)

This quote shows that a human rights journalist cannot just choose the news story. He must choose a news source in accordance with the direction of the news to be written. He must reject news sources that mislead the audience's understanding of human rights violations. Even if he is forced to choose a source of news that is credible but misleading, he must have the courage to include sources that can provide a true picture of reality.

The selection of sources like this was carried out in the news item 'Check the Facts of Mahfud MD Claim: There were no Human Rights Violations in the Jokowi Era?' (tirto.id, 2019). The news item stated that the Coordinating Minister for Politics and Security, Mahfud MD, issued a statement that human rights violations had never happened during President Joko Widodo's leadership of Indonesia since 2014. The news item added:

As quoted by CNN Indonesia, Mahfud said human rights violations did not occur during the riots in Papua and West Papua. He reasoned that the riot was a riot between the audience and the audience. The authorities, he continued, were deployed to sort out the victims and rioters. (tirto.id, 2019)

Even though Mahfud MD's opinion is misleading, the media cannot possibly ignore the information it conveys. He is a minister coordinator. This position has a significant news value. However, to compensate for the erroneous opinion, tirto.id conveyed information from other sources, namely from the Universal 
Declaration of Human Rights. The news item continued:

When referring to the general understanding in the Universal Declaration of Human Rights, as quoted from the United Nations website, human rights include 'the right to life and freedom, freedom from slavery and torture, freedom of opinion and expression, the right to work and education, and many again. Everyone has the right to these rights, without discrimination.'

In 1976 the International Covenant on Economic, Social and Cultural Rights (ICESCR) and the International Covenant on Civil and Political Rights (ICCPR) emerged. Both of these agreements mentioned in more detail related to basic human rights in the economic, social, cultural, and civil and political fields. If it refers to the understanding of the United Nations, human rights violations are not limited to physical violence. (tirto.id, 2019)

To prove that human rights violations occurred in Indonesia during 2018, tirto. id cited the Annual Report of National Commission on Human Rights 2018. According to the report, the National Commission on Human Rights handled various reports on human rights violations. The news item stated:

[The] National Commission on Human Rights also noted that in the cases they handled, the police were the party most often complained [about] to their institutions with a total of 1,670 files. Corporations and local governments followed with 1,021 files and 682 files respectively.

While related to the classification of rights that were violated from cases that were complained to [the] National Commission on Human Rights, overall there were 11 rights that were violated. The right to justice is the most violated right with 463 cases. The right to welfare followed in second place with 330 cases, then the right to social security of 57 cases, and the right to life of 38 cases. (p. 16) (tirto.id, 2019)

The tirto.id news reported item implies that human rights journalists must have an adequate curiosity about the Universal Declaration of Human Rights, the Covenant on Civil and Political Rights, the Covenant on Economic, Social, and Cultural Rights. However, for human rights journalists in West Papua, curiosity about the above needs to be supplemented by adequate curiosity about the UN Resolution No. 2054, the Act of Free Choice, the Uti Juris Possidetis Principles, the Right to Self-Determination, the Non-Self-Governing Territory, Indonesia's Authority over West Papua, the West Papuan People's Congress, and the Political Status of West Papua.

Still regarding the news reported by tirto.id, is the news one of the best practices of news on human rights violations in West Papua? It is not easy to answer this question without considering the condition of the audience. The audience, said John Hartley (2007), is a redactional society. 'Journalism has 
begun to change from news-gathering to a redactional function: a prime job of the journalist is to shift existing data and make sense of that for audience, not to generate new information.' (p. 19).

This quote implies that human rights journalists need to respect the information that the audience has. Journalists no longer need to add new information. What needs to be done is to deal with the information that the audience has in a more relaxed manner so as to expose the lies that surround human rights violations. In doing so, lies that are often maintained as public opinion can turn into truth.

During this time, the practice of human rights journalism, said Ibrahim Seaga Shaw, followed four orientations, 1) solution rather than [being] victory oriented, 2) truth rather than propaganda oriented, 3) people rather than elite oriented, and 4) win-win rather than win-lose oriented. However, he proposes four other orientations, such as the following:

These are: global rather than selective reporting, a bias in favour of vulnerable voices, a proactive (preventive) rather than reactive (prescriptive) approach to reporting, and an attachment to, rather than a detachment from, victims of violence. It is also human rights orientated (2011, p.116).

At this point a question arises, which orientation will this research choose? Human rights reporters in West Papua are seen as not reporting comprehensive human rights violations in West Papua. As a result, the news of human rights violations in West Papua was very boring. The audience cannot read the solutions offered. The audience also cannot read the complexity inherent in human rights violations in West Papua.

Maybe the press in West Papua does not have journalists who have the qualifications to produce such news. If this reality is true, they need to adopt the four human rights journalism orientations offered by Ibrahim Seaga Shaw. This article also adopts the four human rights journalism orientations.

If the news of human rights violations in West Papua has fulfilled the four orientations above, the news becomes more calming. It will encourage its audience to be wiser in dealing with problems caused by human rights violations in West Papua.

\section{Methodology}

Based on the above explanation, the author can make the level of curiosity of the idea of human rights of West Papuan journalists as the first discipline in writing news about human rights violations in West Papua. This level can be described as:

The scheme (Figure 1) shows four disciplines that can be investigated regarding the role of human rights journalists in reporting news of human rights violations in West Papua. Disciplines 1, 2 and 3 contribute fully in creating news 

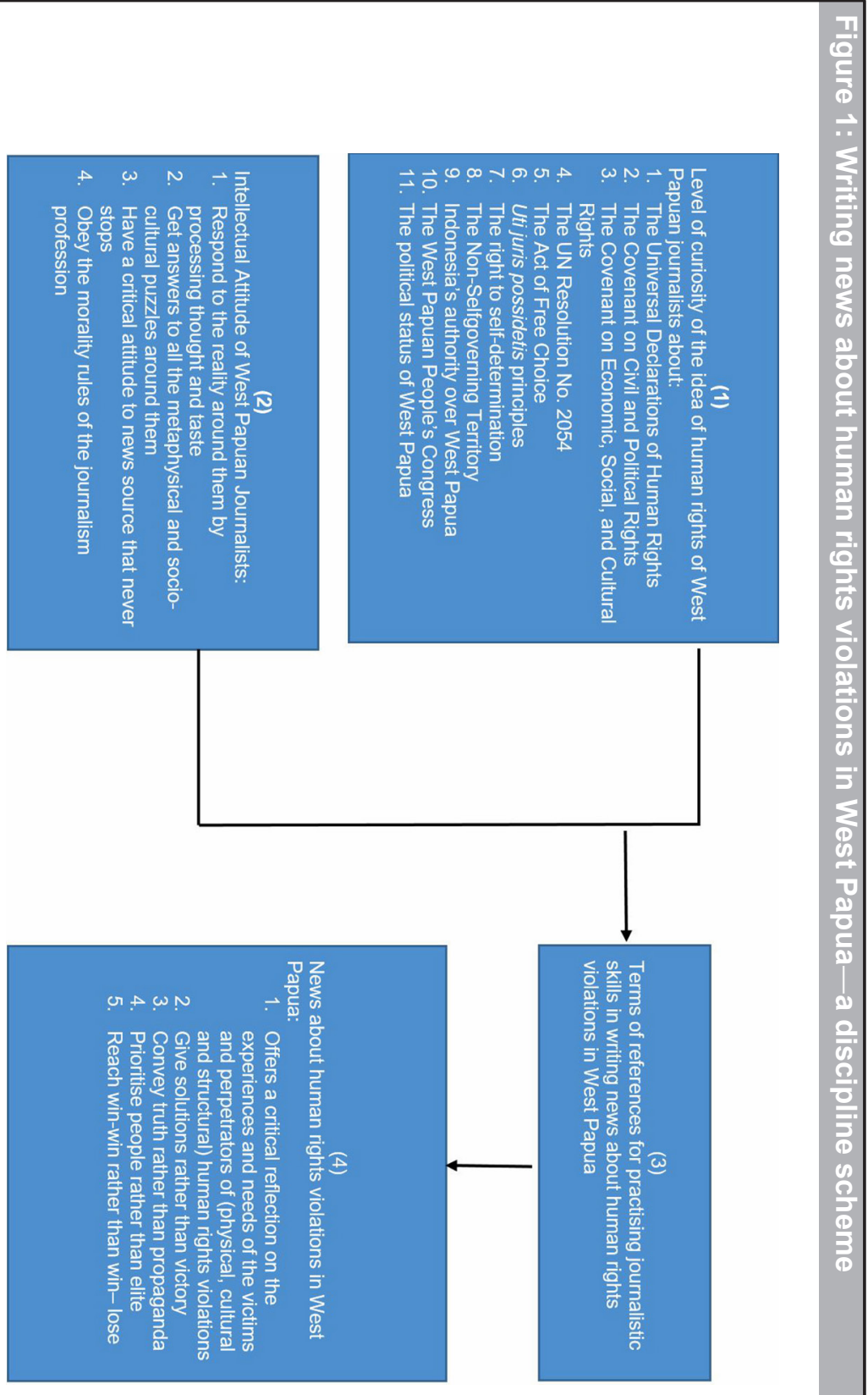
about human rights violations that meet the criteria as written in the discipline 4 . However, each discipline can be studied independently.

This research examines the first discipline because it is more strategic. Journalists' curiosity about the idea of human rights greatly affects the news narrative of human rights violations that they write. It can be a guide in the writing of news about human rights violations in West Papua. In addition, it can guide journalists to write conclusions from the news they report.

To determine respondents, the author first observed the constellation of newspapers published in Jayapura. According to Stanley Adi Prasetyo, when he was chairman of the Press Council, there were five newspapers that were news publishing pioneers in Jayapura: Cenderawasih Pos, Tifa Papua, Jubi, Suara Papua and Papua Post. He continues:

The reformasi era, like other regions, gave birth to many new newspapers. It's easier for people to set up newspapers. Then popped up one by one newspapers in Papua. Interestingly, the birth of these new newspapers originated from two media which have long existed in Papua: Tifa and Cenderawasih Pos. Some of the managers came out and founded new media. When this survey was conducted there were five media being published in Jayapura: Cenderawasih Pos, Tifa Papua, Jubi, Suara Papua and Papua Post. (Prasetyo, 2018)

However, following the social development of the readership, some newspapers turned to online editions, such as Tifa Papua, which became tifapapua. com; Suara Papua became suarapapua.com and Jubi became tabloidjubi.com. Among the three online publications, tabloidjubi.com and suarapapua.com are the most widely reported news outlets about human rights violations in West Papua. According to Reynelda Beatrix Ibo, Benny Mawel from tabloidjubi.com and Arnold Belau from suarapapua.com had been blacklisted by the government (Ibo, 2020). That is why the author chose these two journalists as respondents for this study. Both of them are experienced in writing news about human rights violations in West Papua, and are also known as brave journalists.

With both of these journalists, the author conducted indepth interviews about the discipline. The results of the interviews were confirmed to the concept of journalists as professionals.

\section{Results and discussion \\ Results}

Benny Mawel seeks to know more about the idea of human rights originating from the Universal Declaration of Human Rights, the Covenant on Civil and Political Rights, the Covenant on Economic, Social and Cultural Rights, the UN Resolution No. 2054, the Act of Free Choice, the Uti Juris Possidetis Principles, 
the Right to Self-Determination, Territories Without Self-Government, Indonesia's Authority over West Papua, West Papua People's Congress, to the Political Status of West Papua (see Figure 1-1). However, he believes that he did not need special time to find out. The most important thing for him is to work in accordance with the moral rules of journalism, namely the journalism code of ethics and Law No. 40 of 1999 concerning the press (Mawel, 2020).

When he imagined that he had adequate knowledge about all of the above human rights ideas, he believed he would no longer be a journalist, but a human rights activist and a political activist (Figure 1-2). 'If I understand that, I am a human rights activist and political activist. I am no longer a reporter. So far, I have interviewed my informants with various questions about the things mentioned above,' he said (Mawel, 2020).

Mawel considered that he did not need to understand deeply the history of human rights in West Papua. His knowledge was enough, which was to facilitate the person being interviewed. 'I wrote the results of the interviews,' he added (Mawel, 2020).

'Is my attitude wrong?' Mawel asked. He answered himself, 'No. I want to be a professional journalist. To become a professional journalist, the instructions are there, Law No. 40/1999 concerning the press and journalistic code of ethics' (Mawel, 2020).

Armed with the journalistic skills and the moral rules of journalism, Benny dared to write any news about human rights violations in West Papua. Strictly speaking, he has no fear.

For Arnold Belau, human rights violations in West Papua are not solely the monopoly of the Indonesian military and the Indonesian police. Reports in circulation indeed show civilian casualties, murder, torture, detention without basis, missing persons and rape. However, many public facilities were burned, such as school buildings. This is a violation of human rights that fosters a culture of fear that is very frightening. 'Well, I want to show this culture of fear through the news that I wrote' (Belau, 2020).

To achieve this desire, Belau felt the need to understand Law No. 39/1999 concerning human rights. 'The law guarantees the implementation of human rights such as the right to life, the right not to be tortured, the right to a fair and just legal process. If anyone violates these rights in Papua, I must write it in my newspaper. I am not afraid to write it,' he added (Belau, 2020).

In reporting on human rights violations in West Papua, Arnold Belau continued to uphold the professional attitude of journalists. He must comply with the existing news coverage, starting from Law No. 40/1999 to the journalism code of ethics. 'Did my news educate the public? I'm sure not yet. So I am still looking for a news format on human rights violations in West Papua that educates the public,' he added (Belau, 2020). 
Belau believed his curiosity towards the idea of human rights originating from the Universal Declaration of Human Rights, the Covenant on Civil and Political Rights, the Covenant on Economic, Social, and Cultural Rights, the UN Resolution No. 2054, the Act of Free Choice, the Uti Juris Possidetis Principles, the Right to Self-Determination, the Non-Self-Governing Territory, Indonesia's Authority over West Papua, the West Papuan People's Congress, to the Political Status of West Papua is no longer large. For him, adequate knowledge about all that could even endanger him. He became unfocused in writing news on human rights violations in West Papua. 'Understanding of Law No. 39/1999 on human rights is enough to capture the phenomenon of human rights violations in West Papua,' he added (Belau, 2020).

What stimulates Arnold Belau to write news of human rights violations in West Papua? He admitted that the responsibility for writing about human rights violations in West Papua was the responsibility of his profession. He is obliged to convey information about human rights violations in West Papua to the audience on an ongoing basis. He is not at all afraid of reporting such news in West Papua. However, before writing the news, he must first cross-check the validity of the information. 'It is in this context that I see my work as intellectual,' he added (Belau, 2020).

Belau agreed with the opinion that journalists were intellectuals. However, he admitted that some journalists write news by 'action-reaction', and fulfill administrative obligations without a serious reflection process. 'That is why inaccurate news often appears, data or quote errors occur,' he added (Belau, 2020).

Arnold Belau also admitted that he had subjectivity in reporting human rights violations in West Papua. He was unable to eliminate it altogether. However, he always tried to minimise that subjectivity. 'I want to maintain my credibility and the credibility my media. This is where the real professionalism is,' he said (Belau, 2020).

\section{Discussion}

The results of the interview as a writing genre

Interviewing is one technique to collect facts. The process involves two parties, the interviewer (journalist) and the person being interviewed (the resource person). The interaction between the two determines the interview results. The stimulation of the interviewer is expected to stimulate the news source. So the actual results of the interview are the results of the collaboration of journalists and resource people. Journalists and resource persons are resource people.

If Benny Mawel presents his interview about human rights violations in West Papua with the resource person in the form of 'Question and Answer, or Q\&A', this is a writing genre (Figure 1-3). It was indeed not Benny Mawel's byline writing. However, it cannot be underestimated. It can probe the thoughts 
of the interviewer and the interviewee. It can explain to the reader about human rights violations in West Papua.

We have certainly read the 1963 Alex Haley interview with American black revolutionary Malcolm X (1925-1965) in Playboy magazine. The result is a never-dry source of the philosophy of rebellion, motivation, and ideology of the black student uprising against slavery and the oppression by white Americans. The results are written in the form of ' $Q \& A$ '.

However, Mawel never wrote news about human rights violations in West Papua in the form of ' $Q \& A$ '. He wrote the results of his interviews with speakers embedded in the body of the news. As a result, the news cannot be a source of information about the philosophy, motivation, and history of human rights violations in West Papua.

To be able to write the results of the interview as a genre of writing, Mawel certainly needs to have more human rights ideas. The source of the ideas varied, ranging from the Universal Declaration of Human Rights, the Covenant on Civil and Political Rights, the Covenant on Economic, Social, and Cultural Rights, the UN Resolution No. 2054, the Act of Free Choice, the Uti Juris Possidetis Principles, the Right to Self-Determination, the Non-Self-Governing Territory, Indonesia's Authority over West Papua, the West Papuan People's Congress, to the Political Status of West Papua.

Even if Benny will not write the results of the interview as a genre of writing, knowledge about the things above can also be used as a guide to see the connection of an incident of human rights violations in West Papua with other human rights violations. Actually, a human rights violation event in West Papua never stands alone. It has a connection with the past and will reach into the future.

\section{Educating the audience}

Arnold Belau's acknowledgment that his great curiosity about the idea of human rights originated from the Universal Declaration of Human Rights, the Covenant on Civil and Political Rights, the Covenant on Economic, Social, and Cultural Rights, the UN Resolution No. 2054, the Act of Free Choice, the Uti Juris Possidetis Principles, the Right to Self-Determination, the Non-Self-Governing Territory, Indonesia's Authority over West Papua, the West Papuan People's Congress, and the Political Status of West Papua poses risks to themselves. That knowledge actually helped him capture the process of human rights violations in West Papua. He will also be more critical in facing human rights violations in West Papua. He can even increase his intellectual attitude.

If Belau wants to enlarge his curiosity about these issues, of course he must learn. It is not easy for him to learn anymore. In addition to the time taken to pursue deadlines, he also has to go out into the field, cover both sides and cross-check confirmation. This is from Belau's side. In terms of the audience, 
it is different. The audience does not care about all of Arnold's technical issues. What is important for them is getting the right information which in turn can be used to make decisions on how to deal with the state.

Actually, the audience does not need heavy information. They just want to know the extent to which Indonesia recognises human rights, starting from the right to express an opinion, the right to associate, the right to education, the right of equality before the law and the basis for the birth of all rights. However, human rights violations that have occurred in West Papua made them sceptical of the fulfillment of their human rights. This is where the role of Arnold Belau actually becomes very important. He can present complete information about the relationship of all these things. He provides intelligent and critical information to the audience. He does not merely convey information, but more than that, he needs to educate the audience.

\section{Journalists as professionals}

Benny Mawel does not want to be a human rights and political activist. He wants to be a professional reporter only. This opinion certainly needs to be respected. However, the reasons need to be discussed further.

The essence of political activism, writes Daniel Dhakidae, is contestation with power so that power does not rise through the sky. This, of course, carries risks. What are the risks? Dhakidae asked, 'Prison must always be imagined to be a home' (2009, p. xviii). When Benny Mawel said he did not want to be a political activist, this indicated that he did not want to take the risk mentioned by Dhakidae.

However, Mawel's choice to become a professional journalist does not mean he faces no risk. Risks from his side include that he understands political life in West Papua and Indonesia. If he closes his eyes to that condition, it means he does not care. At first this ignorance will not bother him. However, over time it will make him feel uncomfortable. He must fight with himself.

If his knowledge of the current political situation in West Papua and Indonesia is used to enrich the news about human rights violations in West Papua, the news has a perspective. The audience has become increasingly familiar with the relationship of human rights violations in West Papua to political conditions.

From the audience side, the professional attitude of Benny Mawel must present meaningful news. If the audience does not understand it, they will be disappointed. If the disappointment happens repeatedly, it is not impossible that the people no longer want to read the news written by Benny Mawel. They no longer want to provide information to Mawel.

Arnold Belau also did not mix being a political activist and being a journalist. He consistently goes through his role as a journalist professional. In carrying out this profession, Belau is always considered capable of getting things done. However, in 
the practice of daily journalism, getting things done is a euphemism that complies with whatever principles are ordered by the media. Media orders are often the same as those of the authorities. Then the battle is inevitable.

The fight does not stop there. There is another battle, which is winning the hearts of the audience. It was not enough to just convey information in the form of a portrait of the reality of human rights violations in West Papua. He needs to select events related to the past and shape the future. He needs to capture the process of people's life in West Papua.

People's life in West Papua, according to Todung Mulya Lubis, has fallen into a severe backwardness. They seem to have no more pride (2005, p. 268); though they have given more than 40 years to Indonesia to make them as countrymen. The opportunity was not used, not to say misused. Then it is the duty of Arnold Belau and other West Papuan journalists to raise the dignity of the people of West Papua.

It is in this context that West Papuan journalists deal with their intellectual attitude. He must doubt the public policies that underlie human rights violations in West Papua. They must test every public policy. The attitude of believing in the policy, in essence, makes them arbitrary. More than that, their intellectual enthusiasm is loose. In fact, the intellectual spirit in the work of journalism, as Arnold Belau said above, should not be slack.

In the near future, this effort will change the position of journalists in West Papua to help those whose rights have been violated in West Papua. To aid those whose rights have been violated, said Henry Shue, as quoted by Jack Donolly, is the task of many parties (2006, p. 606).

Based on the above facts, the professional attitude of human rights journalists in West Papua is not only daring to write news because it carries out journalistic skills that is guided by moral values of journalism, but also presents intellectuality in the news they write. Courage is one of the innate qualities of journalists. Borrowing the opinion of Jeremy Paxman, Marie Kinsey (2005) says that journalists are members of the 'awkward squad'.

In practice, human rights journalists need to provide a political perspective on the news of human rights violations they write, elevating the dignity of the Papuan people to create meaningful news for the people of West Papua. It is this professional implementation of journalists who can produce news as written in discipline (Figure 1-2) of the news writing scheme on human rights violations in West Papua.

\section{Making a balance}

After Suharto stepped down as President, there was a demand from the people in West Papua for the press to carry out its traditional functions. Among all the functions, the most awaited in the community is the watchdog function. The 
function of the press like this can only be carried out by the press when it plays the role as a social institution (Abrar, 2011, p. 8). The press now has a prominent position in West Papua as an economic institution. Abrar writes:

In the position as an economic institution, press activity serves advertisers, the function of the press is entertaining, the purpose of the press is to make the press an industry, the obligation of the press is to serve the wishes of the public and the content of the press is factual and fictional. (2011, p. 8)

If the press in West Papua wants to prioritise the watchdog function, it means it must make a balance. The press must give the same attention to the press as an economic and social institution. Could that happen? It is possible, as long as the press strives to achieve the ideal goals of journalism. Various opinions say that the ideal purpose of journalism is to serve the right to know of the audience. Jeffrey Olen wrote, 'Our main task is to serve the right to know of the audience.' (1988, p. 7). Morris Wolfe wrote, 'Because the press is a social institution, journalists must care about the right to know of the community' (1993, p. 95).

In the current condition, the people of West Papua really want a resolution of human rights violations in West Papua. The violations, according to Yan Christhian Warinussy, (2017) are more than 50 years old.

However, according to Neles Tebay, the people of West Papua have experienced human rights violations since 1963 until now. 'The issue of human rights violations in West Papua has not become a major issue in the major media in Jakarta,' he added (VOA Indonesia, 2017).

Therefore, this is an opportunity for the press in West Papua to make human rights violations in West Papua a major issue. To encourage West Papuan journalists to write more educative human rights violations, the authors propose technical guidelines as outlined in this article.

\section{Conclusion}

From the point of view of democracy and human rights, expressing an opinion is universally recognised. Usually the manifestation of expressing that opinion can be through written, oral and other means. Benny Mawel and Arnold Belau have expressed their opinions about the professionalism of human rights journalists in West Papua verbally. In building their professionalism, they feel no need to build greater curiosity about the idea of human rights originating from the Universal Declaration of Human Rights, the Covenant on Civil and Political Rights, the Covenant on Economic, Social and Cultural Rights, the UN Resolution No. 2054, the Act of Free Choice, the Uti Juris Possidetis Principles, the Right to Self-Determination, the Territories Without Self-Government, Indonesia's Authority over West Papua, West Papua People's Congress, and the Political Status of West Papua. What is important for them is to practise the 
journalistic skills guided by the moral framework of journalism in writing facts and data about human rights violations in West Papua.

However, from the point of view of journalism, the above attitude is not enough. Benny Mawel and Arnold Belau need to increase their curiosity about the idea of human rights originating from many sources (see discipline 1 in Figure 1). Another reference is to embody their intellectual attitude to the news they write (see discipline 2). If these two disciplines have become their references in writing news about human rights violations in West Papua using journalistic skills, they will produce news as illustrated in discipline 4 .

If this conclusion is seen as something lacking with West Papua journalists in reporting news about human rights violations in West Papua, surely it is necessary to improve the news writing. However, improvements will not occur only through an appeal. Opportunities for improvement must be created by those who pay attention to the news about human rights violations in West Papua. No matter who the party is and what they do, it will be more valuable to improve the news of human rights violations in Papua. To begin, the author suggests that Papua Institute of Science and Technology publish the guidelines for writing news about human rights violations in West Papua.

\section{Note}

1 After the 1969 Act of Free Choice, West Papua became part of Indonesia as the easternmost province of Indonesia. However, in 2003 Indonesia divided the province into two provinces, Papua and West Papua. West Papua in this article refers to the West New Guinea region.

\section{References}

Abrar, A. N. (2011). Analisis pers: Teori dan praktek. (Press analysis: Theory and practice).

Yogyakarta, Indonesia: Cahaya Atma Pustaka.

Abrar, A. N. (2015). Tatakelola jurnalisme politik (Governance of political journalism). Yogyakarta, Indonesia: Gadjah Mada University Press.

Adnan, Z F. (2020). Interview with the author, May 25.

Belau, A. (2020). Interview with the author, February 15.

Ceposonline.com. (2019, Desember 9). 71 Tahun hari HAM, Potret buram pelanggaran HAM di Papua (71 Years of human rights day, A blurred portrait of human rights violations in Papua). Berita utama (Headlines).

Dhakidae, D. (2009). Pengantar (Introduction). In, Lubis, T.M., Dari kediktatoran sampai Miss Saigon (From dictatorship to Miss Saigon). Jakarta, Indonesia: Penerbit PT Gramedia Pustaka Utama.

Donolly, J. (2006). Human rights. In J. S. Dryzek, B. Honig, \& A. Phillips (Eds.) Political theory. Oxford, UK: Oxford University Press. 
Hartley, J. (2007). Journalism as a human right: The cultural approach to journalism. In M. Loffelholz \& D. Weaver (Eds.), Global journalism research theories, methods, findings, future. New York, NY: Peter Lang Publisher.

Haley, A. (1963, May). Malcolm X: The Playboy Interview. Playboy. Available at: https:// genius.com/Playboy-playboy-interview-malcolm-X-annotated

Ibo, R.B. (2020). Interview with the author, February 1.

Kinsey, M. (2005). Journalist. In B. Franklin, M. Hamer, M. Hanna, M. Kinsey \& J. E. Richardson (Eds.), Key concepts in journalism studies. London, UK: Sage Publications.

Kleden, L. (1978). Manusia: Kerinduan yang tak Selesai (Humans: Unfinished longing. Dalam Horizon, Majalah Sastra No. 1 Tahun XIII, Januari. Jakarta, Indonesia: Yayasan Indonesia.

Lubis, T.M. (2005). Jalan Panjang Hak Asasi Manusia (The long way to human rights). Jakarta, Indonesia: Penerbit PT Gramedia Pustaka Utama.

Mawel, B. (2020). Interview with the author, February 14.

Motuloh, O. (2019). Reformasi dan pilpres 2019 vox populi, hoax pedul (Reform and presidential election 2019 vox populi, hoax cares). In R. Yuniar, Pilpres \& jurnalistik hitam putih (Presidential election \& black and white journalism). Jakarta, Indonesia: Yayasan Pustaka Obor Indonesia.

Olen, J. (1988). Ethics in journalism. Englewood, NJ: Prentice Hall.

Prasetyo, S.A. (2018, September 24). Potret pers dan media di Papua: belum hadir memenuhi hak atas informasi oleh: Stanley Adi Prasetyo (Portrait of the press and media in Papua: not yet present to fulfill the right to information by: Stanley Adi Prasetyo). Retrieved on January 26, 2020 from https://dewanpers.or.id/berita/detail/1026/ Potret-Pers-dan-Media-di-Papua:--Belum-Hadir-Memenuhi--Hak-Atas-InformasiOleh:-Stanley-Adi-Prasetyo.

Shaw, I.S. (2011). Human rights journalism: A critical conceptual framework of a complementary strand of peace journalism. In I. S. Shaw, J. Lynch, \& R. A. Hackett (Eds.), Expanding peace journalism: comparative and critical aprroaches. Sydney, NSW, Australia: Sydney University Press.

Shaw, I.S. (2012). Human rights journalism advances in reporting distant humanitarian interventions. London, UK, Palgrave Macmillan.

Siregar, A. (1985). Catatan pendahuluan dari penyunting: Perjalanan panjang mencari corak (Introductory notes from editor: Long journey in search of patterns). In A. Siregar (Ed.), Profesi wartawan di mata saya (Professional journalists in my eyes), Yogyakarta, Indonesia; Lembaga Penelitian, Pendidikan dan Penerbitan Yogyakarta.

Sobary, M. (1995). Moralitas Kaum Pinggiran (Peripheral morality). Bandung, Indonesia: Penerbit Mizan.

Tirto.id. (2019, December 17). Periksa fakta klaim Mahfud MD: Tiada pelanggaran HAM di era Jokowi? (Check the facts of Mahfud MD's claim: There are no human rights violations in Jokowi's era?). Periksa fakta (Check the facts).

Undang-undang republik Indonesia No. 40 Tahun 1999 tentang pers (Law of Republic of Indonesia number 40 of 1999 concerning the press).

Veronica. (2006). Politik jurnalisme, bukan politik virgin (The politics of journalism, not virgin politics). In Respons, Jurnal Etika Sosial Volume 11, No. 01, Juli. Jakarta, Indonesia: Pusat Pengembangan Etika Unika Atma Jaya, pp. 16-28.

Voa Indonesia (2017, December 15). Survei LIPI: Pelanggaran HAMpersoalan terbesar di Papua. (LIPI Survey: Human rights violations are the biggest problem in West Papua). Retrieved from https://www.voaindonesia.com/a/survei-lipi-pelanggaran- 
ham-persoalan-terbesar-di-papua/4164959.html.

Warinussy, Y.C. (2017). Melawan lupa: 50 tahun pelanggaran HAM oleh pemerintah RI di tanah papua (bagian II/ selesai) (Fight forgetting: 50 years of human rights violations by the Indonesian government in Papua (part II/completed), Suara Papua. com, August 7. Retrieved from https://suarapapua.com/2017/08/07/melawan-lupa50-tahun-pelanggaran-ham-oleh-pemerintah-ri-di-tanah-papua-bagian-iiselesai/

Wignjosoebroto, S. (2005). Pengantar (Introduction). In Lubis, T.M., Jalan panjang hak asasi manusia (The long way to human rights). Jakarta, Indonesia: Penerbit PT Gramedia Pustaka Utama.

Winda, E. (2015, February 15). Ada wartawan, ada reporter, ada jurnalis. Apakah mereka berbeda? (There are reporters, there are journalists. Are they different?). Retrieved on January 21, 2020 from https:// careernews.id/issues/view/3082-Ada-WartawanAda-Reporter-Ada-Jurnalis-Apakah-Mereka-Berbeda.

Wolfe, M. (1993, December 21). Frozen corpses and other essential information, The Globe and Mail.

Ana Nadhya Abrar is the author of Wellington Lod Wenda: Pemimpin Papua Yang Takut pada Tuhan (Wellington Lod Wenda: Papuan Leader Who Fears God), biography of the former regent of Pegunungan Bintang Regency and Don A.L. Flassy: Pencetus Gagasan Mengawal Ideologi Papua (Don A.L. Flassy: The Originator of the Idea of Guarding Papuan Ideology), a biography of the Secretary of Papua Presidium Council.

ana.abrar@mail.ugm.ac.id 